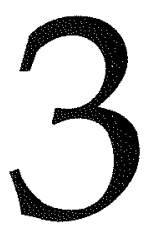

\title{
Constitutional engineering and the alternative vote in Fiji: an assessment
}

\section{Ben Reilly}

The single most important institutional issue for encouraging the development of peaceful multi-ethnic politics in Fiji is the design of the new electoral system. Electoral systems have long been recognised as one of the most important institutional mechanisms for shaping the nature of political competition-first because they are, to quote one electoral authority, 'the most specific manipulable instrument of politics' (Sartori 1968:273)-that is, they can be purposively designed to achieve particular outcomes-and second, because they structure the arena of political competition, offering incentives to behave in certain ways, and rewarding those who respond to these incentives with electoral success. The great potential of electoral system design for influencing political behaviour is thus that it can reward particular types of behaviour and place constraints on others. In terms of ethnically divided societies, for example, where ethnicity represents a fundamental political cleavage, particular electoral systems can reward candidates and parties who act in a cooperative, accommodative manner to rival groups; or they can punish these candidates and instead reward those who appeal only to their own ethnic group. Unfortunately, most academic studies of electoral systems are largely silent on the potential for electoral systems to produce these kinds of incentives. ${ }^{1}$ 
It is therefore a pleasure to assess the report of the Fiji Constitution Review Commission (CRC), which deals directly and comprehensively with these issues (Fiji CRC 1996). The Commission's report puts forward a compelling argument for utilising the electoral system to promote multi-ethnic politics in Fiji. In doing so, it presents a well-reasoned intellectual case for the virtues of 'vote pooling' for future Fijian elections, via the use of a preferential electoral system known as the Alternative Vote. Despite some technical misjudgements (which, I argue, can be corrected relatively easily), the overall depth and quality of the report make it a significant contribution to the field of constitutional engineering, and it deserves to be widely read and acted upon in the years ahead.

This chapter provides an assessment of the Commission's electoral system recommendations. First, I will show how the Alternative Vote (AV) works to promote accommodative behaviour both in Australia, where it is a well established feature of elections at the national and state level, and how it worked when used in another South Pacific state, the then Territory of Papua New Guinea, between 1964 and 1975. This second example is particularly important, not only because it represents the only example of the use of AV in a plural society, but also because an analysis of the three elections held under AV rules in Papua New Guinea provide detailed evidence of how AV influences campaigning strategies and promotes accommodative and cooperative behaviour in an environment with some similarities to Fiji.

Second, I will turn to the Commission's specific recommendations for $\mathrm{AV}$ in Fiji, which involve a departure from the type of AV used in Australia and Papua New Guinea towards a confused hybrid model. This hybrid model of electoral system represents the Commission's major 'technical misjudgement' mentioned above. I will show how and why this proposed hybrid model cannot and will not work in Fiji (or anywhere else, for that matter) and how it may instead, if adopted, deliver unpredictable and even nonsensical results which will not promote inter-ethnic accommodation. Essentially, I am arguing that the Commission got the big picture decision of which electoral system to use right, but then got some of the details wrong. While this is understandable in what can be a highly technical area, it nevertheless means that the specific system recommended by the 
Commission will, if adopted, produce the opposite of the effects intended. I will show why this is so.

Third, I will make some recommendations, within the framework of the Commission's report, for what systems will work to produce the conciliatory multi-ethnic politics advocated by the Commission. These are actually very close to the Commission's own recommendations: either conventional AV in single-member districts, or the Single Transferable Vote if multimember districts are required. I will argue that the key question to be addressed is whether, in the Fiji context, it is possible to draw single-member districts which are sufficiently ethnically mixed-heterogeneous-to allow meaningful cooperation between ethnic groups to take place. If it is, then I would recommend straight, single-member AV, as used in Australia. If multimember electorates are required to ensure sufficient heterogeneity, then I would recommend the use of STV in small, three-member districts. These recommendations will be based on my experience as a consultant to governments in the electoral systems field and on my research into the effects of particular electoral systems in divided societies in the Asia Pacific (Reilly 1997a, 1997b).

\section{The Alternative Vote in action}

The Alternative Vote (AV) was first developed as a modification of the Single Transferable Vote (STV) system of Proportional Representation (PR) - the system recommended by the Street Royal Commission of 1975 for Fiji-which would enable preferential elections to take place in single-member districts, rather than the large multimember electorates required for Proportional Representation (Reilly and Maley 1996). Both STV and AV oblige voters to rank-order all candidates in order of their preference from 1 onwards. The difference between the two systems is manifested in the way votes are translated into seats. Under STV, candidates must gain a 'quota' of votes for election-usually defined as the number of votes divided by one more than the number of seats to be filled, rounded up to the next whole number. In a case where three candidates are to be elected, the quota for election will thus be just over a quarter of all votes. The AV, by contrast, applies this same formula to the election of only one member, so that the quota for election is much higher: 50 per cent plus one. This requires a 
candidate to receive an absolute majority of votes in order to win election, and it is thus rightly classified as a 'majoritarian' system. Under AV, if no candidate has an absolute majority of first preferences, the candidate with the lowest vote total is 'eliminated' and his or her ballots are re-examined for their second preferences, which are assigned to the remaining candidates in the order as marked on the ballot. This process is repeated until one candidate has over 50 per cent of all votes, and is declared elected.

The argument for the accommodative effects of AV are premised on the assumption that politicians are rational actors who will do what needs to be done to gain election. Under AV, 'what needs to be done' varies considerably depending on the makeup of the electorate. Where one candidate is confident of achieving an absolute majority of first preferences, they need only focus on maximising their own vote share from their own supporters in order to win the seat. In cases where no candidate has outright majority support, however, the role of second and later preferences becomes crucial to attracting an overall majority. Those candidates who successfully 'pool' both their own first preferences and the second preferences of others will be more successful than those who fail to attract any second-order support. To 'pool' votes, candidates need to attract the support of groups other than their own, and this is usually achieved by their moving to the centre on policy issues to attract floating voters, or by successfully accommodating 'fringe' issues into their broader policy. There is a long history of both these types of behaviour in Australian elections (Reilly 1997a).

\section{The Alternative Vote in Australia}

The Alternative Vote was introduced by the Nationalist government in Australia in 1918 to replace the existing First-Past-the-Post system after it became clear that several aligned conservative candidates all standing in the same electorate could split their vote between them under First-Past-the-Post, thus handing victory to the less popular but more disciplined Labor Party forces. Its introduction was thus intimately related to the need to counter the possibilities of vote splitting and to encourage and reward collaboration or coalition arrangements between parties (Graham 1968). This ability to aggregate aligned interests, rather than divide them, has long been a (largely unrecognised) feature of Australian electoral politics. The 
most graphic example of this process in action occurred at the 1990 federal election in Australia, where the incumbent Australian Labor Party was polling badly and looked to be heading for electoral defeat, and where voter support for left-of-centre parties such as the Australian Democrats and Greens reached its height. The then Prime Minister, Bob Hawke, went on national radio to campaign directly for the second preferences of these parties' supporters, offering policy concessions on key issues (for example, the environment) and arguing that the Labor Party was far closer to their interests than the major alternative, the Liberal/National coalition (Hughes 1990). This strategy was markedly successful: with minor party support levels at an all-time high of around 17 per cent, the ALP was the beneficiary of around two-thirds of all preferences from Democrat and Green voters-a figure which probably made the difference between it winning and losing the election (Papadakis and Bean 1995). This was thus a 'win-win' situation for both groups: the ALP gained government with less than 40 per cent of the first preference vote, while the minor parties, who did not win lower house seats, nonetheless saw their preferred major party in government and committed to favourable policies in their areas of concern.

Analyses of the effects of AV in Australia have tended to concentrate almost exclusively on its partisan impacts. Some commentators have seen the system as an instrument for maintaining the dominance of the two major parties, the ALP and the Liberal/National Coalition, and for restricting the role of minor parties in the lower house to one of influencing the policies of the major parties rather than gaining election themselves (Papadakis and Bean 1995). Others claim that it can enhance the power and position of minor parties, especially if they have the potential to hold the balance of power between two major parties (Aitkin et al. 1989:150). There is widespread agreement that AV has facilitated coalition arrangements such as that between the Liberal and National parties, and that it works to the advantage of centre candidates and parties, encouraging moderate policy positions and a search for the 'middle ground' (Bean 1986:65). The sometimes fiery and aggressive rhetoric of Australian politics has often distracted observers from recognising just how much cooperative behaviour there is between parties-via preferenceswapping deals, for example-and how close the major parties are on most substantive policy issues. There is little doubt that the AV 
electoral system provides a significant institutional incentive for these tendencies.

Despite the fact that Australia is one of only two countries which currently uses AV to elect its national legislature, most of the interest in the system in recent years has been international in origin. ${ }^{2}$ The potential benefits of AV for encouraging collaboration and accommodation between competing interest groups saw it recommended as the most suitable electoral system for postapartheid South Africa (Horowitz 1991a). The former Australian Territory of Papua New Guinea, which used AV until independence in 1975, has been the site of a long-running campaign for the reintroduction of $\mathrm{AV}$, with much attention focused on the potential of the system to encourage moderate campaigning, reduce candidate numbers and nullify the effects of 'vote splitting'. In addition, another ethnically divided polity in the Asia Pacific region, Sri Lanka, has used a form of preferential voting to elect its president since 1978. Details of these cases and others can be found elsewhere (see Reilly 1997a). For the purposes of this discussion, I want to briefly focus on how AV worked in Papua New Guinea, because I believe this is by far the most illuminating example for those interested in Fiji.

\section{The Alternative Vote in Papua New Guinea}

We have seen above how AV can work to encourage the aggregation of common interests, via the exchange of preferences, in the case of a stable western polity, Australia. While the circumstances in ethnically divided societies are very different, the same broad approach can be used to induce inter-ethnic bargaining and promote accommodative behaviour. At the core of this approach is the need, as Donald Horowitz has argued, 'to make politicians reciprocally dependent on the votes of members of groups other than their own' (Horowitz $1991 \mathrm{~b}: 471)$. The most reliable way of achieving this aim, naturally enough, is to offer sufficient electoral incentives for campaigning politicians to court voter support from other groups. In deeply divided societies, this can be very difficult to achieve. Under conditions of primarily ethnic political identity, for example, policybased cleavages are considerably less salient than ethnic or linguistic identities, and almost nothing will convince a member of one ethnic group to cast his or her vote for a member of a rival group. However, 
under $\mathrm{AV}$ a voter can give a first preference vote to a member of his or her ethnic group, but then use lower-order preferences to indicate secondary choices. Where a candidate needs the support of other ethnic groups to gain election, there is a powerful incentive for him or her to reach out to these groups in search of these second preferences. There is thus an inbuilt centripetal spin within AV: those candidates and parties who are broadly attractive to others will tend to be rewarded, those who have polarised support will generally not. Ideally, candidates who are elected will be dependent on the votes of groups other than their own for their parliamentary positions, and can be expected to serve the needs of these groups as well as their own ethnic group if they are to establish their positions and gain reelection.

The only time that these theories have been properly tested have been in pre-independence Papua New Guinea (PNG), which held elections in 1964, 1968 and 1972 under AV rules. The Constitution Review Commission mistakenly claimed that there is no actual experience of AV...in heterogeneous constituencies in an ethnically divided country' (Fiji CRC 1996:316). The PNG case represents just that. Papua New Guinea is a Melanesian society in which political affiliation rests predominantly on an exceptionally diverse ethnic and linguistic basis of several thousand 'clans' - ascriptive extended family networks which are the primary, and often the only, unit of political and social loyalty. With over 800 separate languages and several thousand tribal groups, this clan-based level of ascriptive ethnic identity means that Papua New Guinea is one of the world's most heterogeneous societies.

We are fortunate that all of Papua New Guinea's elections to date have been the subject of major book-length election studies (Bettison et al. 1965; Epstein et al. 1971; Stone 1976; Hegarty 1983b; King 1989; Oliver 1989; Saffu 1996). These studies provide a wealth of comparative information on political behaviour in the context of an electoral contest. Crucially, they detail numerous instances of accommodative vote pooling and preference-swapping activities under AV; and increasingly violent, zero-sum campaign behaviour since the replacement of AV with First-Past-the-Post in 1975. Essentially, there is significant evidence that accommodative vote pooling behaviour was encouraged by the incentives presented by $\mathrm{AV}$, and further significant evidence that behaviour became markedly less accommodative upon 
the introduction of First-Past-the-Post, under which the incentives for electoral victory are different (Reilly 1997b).

Under AV, vote pooling took place in three primary ways, all of which were predicated on the assumption that most voters would invariably give their first preference to their own clan or 'home' candidate. The most common and successful method of vote pooling was for a candidate who had a limited 'home' support base to campaign widely for second-level support amongst rival groups. This required a range of techniques, such as translating campaign speeches and travelling widely throughout an electorate, with the essential request being not for a first preference vote but for a second preference. This enabled electors to cast their primary vote for their 'home' candidate-an essential element in cases of ascriptive ethnic identity-but to also indicate their second choice if their ascriptive candidate was not elected. For this strategy to succeed, candidates needed to be able to sell themselves as a good 'second-best' choicewhich meant, in general, someone who would look after all groups, not just his own. At the first AV elections in 1964, for example, Bill Bloomfield in the Kaindi electorate emerged as the winner of the seat after the preferences of seven candidates had been distributed. Without a strong local support base or home area, Bloomfield campaigned extensively, translated his speeches into local dialect and emphasised that if electors did not want to give him their first preference 'then give me number two'. This was a highly effective strategy which saw him carry a seat that he would have had no chance of winning on first-preferences. Similarly, the contest for the seat Henganofi provided a classic example of the way disciplined preference-swapping amongst a group of aligned candidates can overcome a single dominant plurality winner (see Table 3.1). Candidate Bono, with massive support from his own region but negligible support elsewhere, lost to candidate Ugi, situated in the centre of the electorate and attracting a smaller clan block vote but a considerably broader range of support. Ugi was well behind on first preferences, but gained the majority of all other candidate's preferences to win the seat. 
Table 3.1: Allocation of preferences in Henganofi Electorate, 1964

$\begin{array}{lccccc}\text { Candidate } & \text { 1st count } & \text { 2nd count } & \text { 3rd count } & \text { 4th count } & \text { final count } \\ \text { Forapi } & 787 & - & - & - & (787) \\ \text { Posi } & 1758 & 12 & - & - & (1770) \\ \text { Punupa } & 3708 & 73 & 41 & - & (3822) \\ \text { Bono } & 8028 & 12 & 35 & 224 & 8299 \\ \text { Ugi } & 3295 & 667 & 1362 & 3274 & 9228 \\ \text { Exhausted }^{a} & - & 23 & 334 & 324 & 681\end{array}$

Note: ${ }^{\text {a }}$ An 'exhausted' vote comprises a ballot under an optional preference marking system in which preferences have not or cannot be assigned to a continuing candidate, hence 'exhausting' before the full distribution of preferences.

Source: Chief Electoral Officer, 1964. Statistical returns showing the voting within each open and special electorate in relation to the General Election for the House of Assembly, 1964, Government Printer, Port Moresby.

A second strategy for victory under $\mathrm{AV}$ was for candidates with significant existing support bases to reach out to selected allies for secondary support. Traditional tribal contacts and allegiances, for example, could be utilised to create majority victors. This similarly necessitated a commitment to behave positively towards those groups if elected. In the Dei Open Electorate at the 1972 elections, for example, tribal leaders of previously hostile clans made deals with each other for preference support. The winning candidate forged particularly close connections with a traditional ally tribe via 'intensive ties of ceremonial exchange', urged his supporters to cast their preferences for a member of a hostile rival tribe as well as for himself, and consequently received a generous proportion of that opponent's second and later preferences to win the seat.

A third strategy, and increasingly common by the time of the third AV election in 1972, was for groups and candidates to form mutual alliances, sometimes campaigning together and urging voters to cast reciprocal preferences for one or the other. This necessitated a strong cooperative approach to electoral competition, in stark contrast to the zero-sum attitudes that have prevailed at elections since independence in 1975, when Papua New Guinea changed to a FirstPast-the-Post system. At the first post-independence election in 1977, David Hegarty found that vote splitting and other 'anti-system' 
tactics 'heightened tension between clans and groups and in some cases polarized electorates to the point of violent conflict...this situation contrasted markedly with campaigning styles in previous elections where opposing candidates often toured their electorates together urging voters to cast preferences' (Hegarty 1983a:15).

Despite problems of literacy and numeracy, the percentage of voters in Papua New Guinea utilising preferences increased with every election between 1964 and the last preferential voting election in 1972, where 70 per cent of all seats were decided on preferences. In addition, the incidence of preference distribution deciding outcomes increased over time. By 1972, 16 per cent of seats returned different members than would have been the case under a straight First-Pastthe-Post contest. These are much higher rates of preferences being counted and results being changed than has ever been achieved in national elections in Australian, the 'home' of AV, and reflects the way AV works in situations of highly fragmented support.

There is thus a considerable accumulation of hard evidence that AV did serve to encourage cooperative and accommodative political strategies and behaviour in Papua New Guinea. There is also considerable evidence for the obverse: that is, that when incentives for cooperation were removed, ethnic groups reverted to their traditional hostilities. This return to conflict was considerably enhanced by a new set of incentives for non-accommodative behaviour inherent under a First-Past-the-Post, which rewarded vote splitting and appears to have contributed to zero-sum campaigning styles. Attempts since 1975 to constrain these activities have generally proved unsuccessful: candidates have reacted to the electoral incentives of the First-Past-the-Post by focusing their energies on maximising their own clan vote, and in many cases by restricting the campaigning of opposition candidates, via threats of violence, to their own home areas (Standish 1996; Dinnen 1996). This has led to candidates being elected on increasingly minuscule pluralities, and to ever-increasing numbers of candidates standing for election: the higher the number of candidates, the smaller the total vote needed to gain a plurality and hence win the seat (Reilly 1996).

The significance of the PNG example for Fiji is clear: it provides detailed evidence of how and why AV promotes inter-ethnic 
accommodation. And Fiji, as a part Melanesian country, does itself have many social structures in common with Papua New Guinea within its indigenous population. There are two crucial differences, however. One is that the ethnic division in Fiji is a bipolar one between the native Fijian and Indian populations, rather than fractionalised between many different groups, as it is in Papua New Guinea. Second, the combination of the communal electoral system and the mixture of Polynesian and Melanesian elements in indigenous Fijian society-such as the existence of traditional chiefs, for example-means that there has traditionally been less intense competition for elected office in Fiji than in other Melanesian countries, and thus that the lessons of the PNG case may not hold true in Fiji. To assess the way AV will work in Fiji realistically, we must first assess the CRC's specific proposals, and it is to this subject which I will now turn.

\section{The CRC's recommendations}

The recommendations for an AV electoral system in Fiji are set out in detail in chapter 10 of the CRC's report (and summarised in Chapter 2 of this book). The Commission argues-persuasively I think-that AV would encourage multi-ethnic government, would fit in well with Fiji's existing multi-party system, would provide incentives for moderation and cooperation across ethnic lines, and would effectively represent constituents. They noted the appropriateness of using AV in single-member constituencies, but went on to argue that $\mathrm{AV}$ could also be used effectively in multimember constituencies by adding first, second and third preferences together before eliminating the candidate with the lowest numbers of votes. These two recommendations-that multimember rather than single-member electorates be used, and that first, second and third preferences be added together before the elimination of lower-placed candidates begins-represent a significant departure from $A V$ as used in Australia and Papua New Guinea which (with one exception which I will discuss below) have always utilised single-member districts and counted each preference separately. As I will show, the combination of the recommendation that $\mathrm{AV}$ be used in multimember districts, and the recommendation that first, second and third preferences be 
combined when counting votes, together represents a crucial error in the CRC's reasoning.

\section{AV in multimember districts}

The only time that $\mathrm{AV}$ has been used in multimember districts was in the Australian Senate between 1919 and 1946. In contrast to the CRC's claims that $A V$ can be used successfully in multimember constituencies, this experience was anything but a success, producing winner-take-all outcomes and extremely lopsided parliaments. This was because when $\mathrm{AV}$ is used in multimember districts, the majoritarian features of the system become overwhelming. In effect, each vacancy was filled by a separate election, but with the same electorate voting at each. This showed a strong tendency to produce an outcome under which the same party grouping won every seat, and produced such sustained periods of single-party dominance that on a number of occasions the Senate was scarcely workable as a legislative body, let alone as a house of review. In the period from. 1947 to 1950, for example, there were only three opposition Senators-a leader, a deputy leader, and a whip-facing 33 government Senators (Reilly and Maley 1996). This level of system dysfunction meant that the electoral system itself was primarily responsible for the erosion of public confidence in, and the legitimacy of, half the federal Parliament; some have argued that it increased popular opposition to any strengthening of the federal government's powers (see Goot 1985:226). Multimember AV was replaced with the Single Transferable Vote in 1948 which, having been designed for multimember constituencies, has operated in a far more logical way.

The inappropriateness of multimember AV evidenced by the case of the Australian Senate was such that no proposal for multimember $\mathrm{AV}$ has ever again been forthcoming in Australia. Horowitz did propose that multimember AV may have to be used to ensure sufficient electorate-level heterogeneity in the case of South Africa, and it is notable that most critiques of his proposal focused on the unworkability of multimember AV as one of their major criticisms (Lijphart 1991; Reynolds 1995).

\section{Combining first, second and third preferences}

So the first major problem with the CRC's proposal is the recommendation that a majority-style method be used in a situation of choosing 
three, rather than one, representatives-a situation which requires some form of proportional system to work well. The experience of multimember AV elections for the Australian Senate-which also utilised three-member districts-resulted in the most disproportional electoral results ever experienced at any Australian elections. This, however, is not the only problem with the system as proposed by the $\mathrm{CRC}$. The CRC also suggested that, to avoid problems of intra-party competition

in elections for the three-member seats in the Bose Lawa, the first, second and third preferences given to each candidate should be added together, before the candidate with the lowest number of votes is eliminated (Fiji CRC 1996:329).

This is the most unusual aspect of the CRC's electoral recommendations, as it introduces a completely new approach to the counting of preferences which has never been used anywhere else. Essentially, the effect of this recommendation is to count a second and third preference as being of the same value as a first preference. This will, according to the Commission, result in party slates where members are not competing with each other for votes-thus, presumably, strengthening internal party solidarity. Unfortunately, as I will show, whatever positive effects this may have are overwhelmingly outweighed by the capricious and often arbitrary results that this provision will deliver.

The easiest way to demonstrate the problems caused by counting the first three preferences together is to conduct a hypothetical count. I have taken the sample ballot paper produced at p. 321 of the Commission's report, which consists of a hypothetical three-member election in the Vunivadra Open constituency contested by the Viti Liberal Party, the Fiji First Party, the National/Republic Coalition and some independents (see Table 3.2). I have assumed that there are 11,000 voters in the constituency, that there is a slim overall indigenous Fijian majority of electors, that electors vote along ethnic and party lines, and that support for the parties stands at 15 per cent for the Viti Liberal Party, 40 per cent for the Fiji First Party and 35 per cent for the National Republican Coalition, with Independents making up the remaining 10 per cent.

As you can see, most voters follow the party's suggested ordering of candidates - that is, most give the first candidate on the party list their first preference, the second candidate on the list their second 


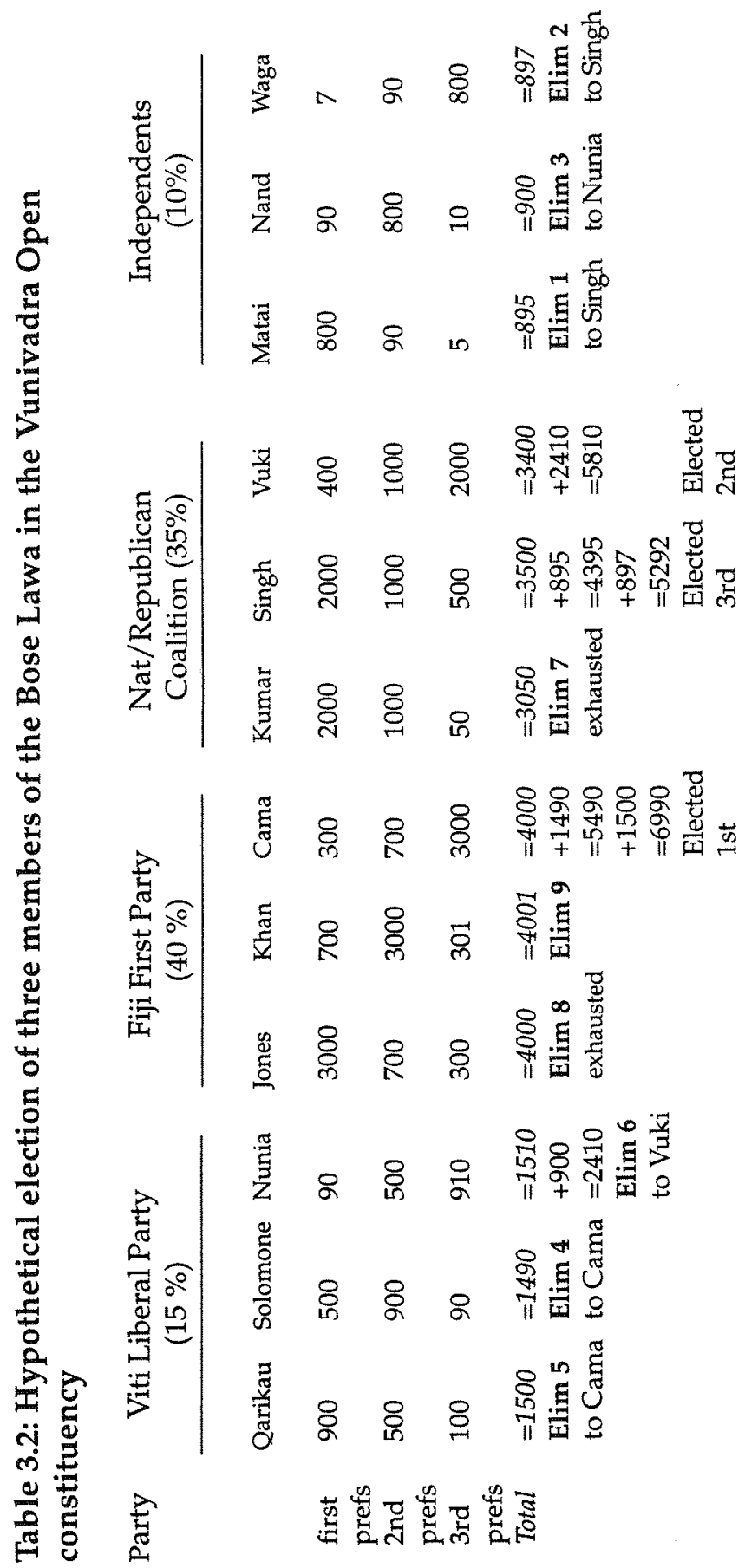


preference, and the third candidate their third preference. Because these are added together, most party candidates end up having very similar vote totals when the first, second and third preferences are aggregated (see the row marked 'Total'). This is the first problem we can see: that the adding together of preferences takes away one of the reasons for using a preferential system in the first place, which is to enable voters to register support for their favoured candidates in order of their choice. The system proposed dilutes this almost to the point of being meaningless. Candidate Jones of the Fiji First Party, for example, is by far the most popular candidate overall, with 3,000 first preferences, but when these are aggregated with second and third preferences he has a total of 4,000 votes - the same as the third placed Fiji First candidate, Cama, who gained one-tenth of the number of first preferences that Jones did. To assume that a third preference and a first preference can be aggregated in this manner is thus to undermine one of the most basic rationales of the Alternative Vote, which is that voters are registering the intensity of their preference when they give someone a first rather than a second or third preference, and that the more first preferences a candidate can gain, the better he or she should do.

This becomes even more apparent when we start the process of eliminating lower-placed candidates and transferring their preferences. The first candidate to be eliminated is the independent candidate Matai, who has 895 total votes (and who gained more first preferences than the other independents, but fewer second and third preferences). Let us assume that all of Matai's preferences go to candidate Singh, the second-placed candidate on the National/ Republican Coalition list. Singh now has 4,395 votes. Candidate Waga, the next to be eliminated, also passes on all his preferences to Singh, who now has a total of 5,292 votes. The preferences of the third independent candidate, Nand, all go to the third Viti Liberal candidate, Nunia, who now has 2,410 votes.

We have now eliminated the three independent candidates, but still have nine candidates left in the race. Six more will have to be eliminated. The next lowest-placed candidate is Solomone of the Viti Liberal Party, who has 1,490 votes. He is the next to be eliminated. This illustrates a second problem with aggregating first, second and third preferences. We are assuming, as the Commission did, that most voters will choose between members of one party with their 
first three preferences before they register their next choice-in other words, that they will be disciplined party voters. In this case, most of the electors who gave their first preference to Solomone would have given their second and third preference to other members of the Viti Liberal Party. However, because we are aggregating first, second and third preferences before we eliminate lower-placed candidates, these preferences have already been counted and we need to look at Solomone's fourth preference to see where the votes should be transferred. In most cases, it will be this fourth preference that determines which candidate will receive a transferred vote. Or, to put it another way, most vote pooling, on which the Commission is relying to encourage inter-ethnic accommodation, will have to take place as requests for fourth-level preference support-which does not augur well for its prospects.

In this case, all of Solomone's fourth preferences go to candidate Cama of Fiji First. So do Qarikau's, who is eliminated fifth. Candidate Cama now has over 6,990 votes. We still have more candidates remaining in the count than available seats, so we need to go on eliminating candidates. The next to go will be Nunia of the Viti Liberal Party, who has 2,410 votes. All his fourth preferences go to Vuki of the National/Republican Coalition. By now it is clear that the election is going to be fought out between the two major parties, who are the only ones left in the race. However, because they did not receive any preferences from the eliminated candidates, the next lowest placed candidates is Kumar of the National/Republican Coalition (3,050 votes) and Jones (4,000 votes) of Fiji First. Jones, you will remember, was the most favoured candidate from any party, gaining 3,000 first preferences, and Kumar was the second most favoured with 2,000. Because, however, first preferences count for the same as third preferences under the Commission's scheme, both are now eliminated. And here we see another capricious paradox of the proposed system. Let us assume that Kumar's supporters gave their fourth preferences to friendly independents, who have all now been eliminated. Similarly, let's assume that most Fiji First voters gave their fourth and later preferences to the Viti Liberal Party or the indigenous Fijian independents. Because both of these groups have also now been eliminated, neither Kumar's nor Jones's votes can be passed on to any continuing candidate. And, because first, second and third preferences have already been aggregated, they cannot 
even be passed on to a running mate. These votes are thus said to 'exhaust', meaning there is no one left in the count to transfer them to. Under a rational preferential vote system, like the Alternative Vote or the Single Transferable Vote, Jones would at least have been able to pass his votes on to his party colleagues Khan or Cama, ensuring that one of them was elected. Under this system, however, these votes are now essentially dead.

There are now four candidates left in the count-Cama with 6,990 , Vuki with 5,810, Singh with 5,292 and Khan with 4,001. Khan is the lowest placed of these and is thus finally eliminated. The final election result is thus Cama elected first, Vuki elected second and Singh elected third. As well as electing the less favoured candidates, it can easily be seen then that the National/Republic Coalition, with only 35 per cent of the vote, was able to gain two-thirds of the seats; the Fiji First Party with 40 per cent of the vote could gain only one, and the overall Fijian majority of electoral support translated into a clear minority of seats. This happened because of the quirks of the preference aggregation system, which counted votes for less popular candidates at the same value as those for more popular candidates. Wily political operators will already have observed the potential for destabilising opposition parties by strategic voting techniques-for instance, instructing your supporters to give their lower preferences to a low-ranked member of an opposition party, thus ensuring that an inferior opposition candidate is elected.

This brief hypothetical example of the system proposed by the CRC should be sufficient to indicate that the aggregation of first, second and third preferences is a questionable practice when applied to a preferential electoral system. It should also demonstrate that the use of a majoritarian system like AV in a multimember context which demands a proportional system is a similarly bad idea. The consequences of such a system can be highly disproportional results-such as the one, in the example above, which gave 67 per cent of the seats to the National/Republican Coalition even though they could only gain 35 per cent of the vote. If replicated in an actual election, this level of disproportionality could well undermine the perceived legitimacy of key institutions of government such as the parliament and the electoral system - the very institutions which most need public support and confidence in Fiji in the years ahead. 


\section{Conclusion}

If the system proposed by the CRC will not produce satisfactory results and promote inter-ethnic accommodation and compromise, then what will? My answer comes straight from the CRC's report, which argued that

the people of Fiji should adopt a voting system that has been used successfully elsewhere, preferably in the region. No unexpected problems would be likely to arise, and there would always be ready access to technical advice and help (Fiji CRC 1996:326).

I strongly concur with these wise words. And, as I have already argued, there is substantial evidence that a preferential electoral system can work to promote inter-ethnic cooperation and harmony, rewarding the centre and promoting broadly-based coalitions. There are two preferential systems with long histories of successful operation: AV in single-member districts, and STV in multimember districts. As the Commission noted, AV in single-member districts is widely used in Australia, at both the federal and state level and, as we have seen, has already been successfully used in Papua New Guinea. STV is used to elect members of the Australian Senate, legislatures in Tasmania and the Australian Capital Territory, and farther afield in Ireland and Malta. I would strongly recommend that the final electoral system chosen for Fiji be one of these two systems.

The choice of which system to adopt comes down to the simple question of whether single-member districts can achieve sufficient diversity in enough electorates to ensure meaningful vote swapping across ethnic group lines, or whether multimember electorates are needed to achieve this. This question was addressed directly by the CRC themselves, who noted the crucial importance of heterogeneous constituencies in facilitating the type of conditions favourable to interethnic vote pooling. The more heterogeneous a constituency, the more likely it is that no one group or party will command an overall majority, and thus the more likely it is that meaningful vote pooling will take place. In most ethnically divided countries, however, members of the same ethnic group tend to cluster together, meaning that the relatively small, single-member districts which are a feature of AV will result in ethnically homogeneous rather than heterogeneous constituencies. The CRC looked at whether, given the distribution of the different communities within the Fiji Islands, it 
would be possible to divide the country into heterogeneous constituencies-that is, one in which there is a reasonable mixture of indigenous Fijians and Indians. They concluded that the choice of 45 single-member or 15 multimember districts 'did not affect the potential for heterogeneity in the more densely-populated areas' but that 'three-member constituencies made it marginally easier to achieve a reasonable degree of heterogeneity' in the less populated areas. They concluded that, for both single and multimember districts, it is 'entirely possible to draw constituency boundaries in Fiji in a way that achieves reasonable heterogeneity' (Fiji CRC 1996:314-15).

If this is correct, then I would recommend the use of singlemember $\mathrm{AV}$, in 45 single-member constituencies. The advantages of this system are clear. It is simple to understand and to operate, it requires an overall majority of support to get elected (thus favouring the political centre and penalising extremes) and, importantly in a rural-based country like Fiji, it enables single-member representation. As the Commission noted, 'voters usually feel strongly that they want to know who their member is and to have access to him or her both individually and as a group with common interests arising from their residence in a particular geographic area' (Fiji CRC 1996:318)a need that, as Joel Barkan has shown, is particularly strongly felt in agrarian societies (Barkan 1995). The other advantage of using AV is that its vote pooling properties work just as well when ethnic divisions transform into other, less destructive cleavages (for example, labour vs capital, for example), as the Commission clearly hopes they will. In this context it is worth noting that, because party support from both major ethnic groups is divided between several parties, even relatively small numbers of one group can present an opportunity for vote pooling. Take, for example, the case of a division in which the population is 80 per cent indigenous Fijian and only 20 per cent Indian. If there is one monolithic Fijian party, then there is no incentive for vote pooling to occur. If, however, there are several parties all bidding for the Fijian vote, as is actually the case in most parts of Fiji, then the majority requirement for election under $A V$ puts the 20 per cent Indian community in a much stronger position, because the Fijian party that gains their support (in the form of second and later preferences) will be more likely to win the seat than others. To do this requires attracting the Indian voters somehow-by 
behaving moderately on ethnic issues, or by offering policy proposals that appeal to the Indian community. Of course, it is also possible to go the other way - for the Fijian parties to 'outbid' each other by being more and more anti-Indian-but such extremism will tend to be punished by AV rather than rewarded. The disadvantages of the system are that, because of the majority threshold, it can underrepresent minor parties and can thus be disproportional-although not as disproportional as the existing First-Past-the-Post system. Overall, the potential of the system for promoting inter-ethnic accommodation would seem to outweigh these drawbacks in the Fijian case.

However, it may be that, contrary to the Commission's expectations, it is not possible to create sufficiently diverse electorates from 45 single-member constituencies. The outer Fijian islands are almost entirely indigenous Fijian, so vote pooling there will have to take place on issues other than ethnic ones, if it takes place at all. The situation on the main islands and in urban centres is more mixed. Some commentators have argued that, even in urban areas, 'ethnic residential self-selectivity' occurs, rendering districts either predominantly Indian or Fijian (Premdas 1995:12). If this means that heterogeneity is impossible in single-member districts, then multimember districts will be necessary. But if multimember districts are necessary, then it is imperative that STV rather than AV be used. STV is similar to AV, but is a system of proportional representation, not a majority system. How proportional it is depends on how many members are chosen. If the Commission's favoured three-member districts are used, then the quota for election is just over 25 per cent, considerably lower than the overall majority required for election under AV. For this reason, the Commission concluded that STV would not work to break down ethnic communal voting to the same extent as AV, as most ethnic groups would be represented in the legislature in the same proportion as their numbers in the general community (Fiji CRC 1996:317). But this only tells half the story. If the hypothetical three-seat election at Table 3.2 had been held under STV rules, for example, the first seat would most likely have gone to the most popular indigenous Fijian supported party, the second to the most popular Indian supported party, and the third seat would most assuredly have been decided on the basis of vote pooling. This would be the case in nearly all three- 
member divisions, provided they were drawn to ensure ethnic heterogeneity. Looked at in this way, a system of 15 three-member constituencies, as proposed by the Commission, would have the advantage of not just encouraging but often requiring vote pooling to take place, at least for the third seat in each district. STV can also be used in two-member districts, where the quota for election becomes quite high-33 per cent-making it more like a majoritarian system than a proportional one. In ethnically mixed constituencies, this would also have the advantage of usually electing one Indian and one Fijian candidate in each district. A further possibility is to use a mixture of single-member seats elected by AV and multimember seats elected by STV, as first recommended by the Street Commission twenty years ago.

So, in conclusion, it seems to me that the two most feasible systems are the ones identified by the Commission itself - but in the form in which they are used elsewhere, rather than the unusual variant proposed by the Commission. Both have their specific advantages-AV is simpler and maintains single-member representation, STV is more complex but also more proportionalbut their similarities outweigh their differences and, in fact, one is a variant of the other. Both have been tried and tested elsewhere. The choice of which electoral system to choose is, of course, ultimately and properly a decision for the Fijian parliament and the Fijian people. I can only conclude by offering the services of International IDEA in this process: as an independent international body established specifically to deal with questions such as these, we would be happy to assist this process in any way we can.

\section{Notes}

1. Notable exceptions include the chapters on electoral systems in two seminal works by Donald L. Horowitz $(1985,1991$ a). See also Sisk (1996).

2. The tiny Pacific micro-state (and former Australian Territory) of Nauru inherited the preferential voting system from Australia but, in a unique departure from the Australian model, combines the preferential counting system with multimember constituencies. Preferences are counted as fractional votes (that is, a second preference is worth half a vote, a third preference is worth a third of a vote and so on). 


\section{References}

Aitkin, D., (ed.), 1985. Survey of Australian Political Science, George Allen and Unwin, Sydney.

Aitkin, D., Jinks, B. and Warhurst, J., 1989. Australian Political Institutions, Longman Cheshire, Melbourne.

Barkan, J., 1995. 'Elections in Agrarian Societies', Journal of Democracy 6(4):106-116.

Bean, C., 1986. 'Electoral law, electoral behaviour and electoral outcomes: Australia and New Zealand compared', The Journal of Commonwealth and Comparative Politics 24(1):57-73.

Bettison, D.G., Hughes, C.A. and van der Veur, P.W. (eds), 1965. The Papua-New Guinea Elections 1964, The Australian National University, Canberra.

Fiji Constitution Review Commission 1996. The Fiji Islands. Towards a United Future, Parliament of Fiji Parliamentary Paper 34 of 1996, Government Printer, Suva.

Dinnen, S., 1996. 'Violence, security and the 1992 election' in Saffu, Y. (ed.), The 1992 PNG Election: change and continuity in electoral politics, Department of Political and Social Change, Research School of Pacific and Asian Studies, The Australian National University, Canberra.

Epstein, A.L., Parker, R.S. and Reay, M. (eds), 1971. The Politics of Dependence: Papua New Guinea 1968, The Australian National University Press, Canberra.

Goot, M., 1985. 'Electoral Systems', in D. Aitkin (ed.), Survey of Australian Political Science, George Allen and Unwin, Sydney: 179-264.

Graham, B.D., 1962. "The choice of voting methods in federal politics, 1902-1918', Australian Journal of Politics and History 8(2):164-79.

Hegarty, D., 1983a. 'The 1977 National Elections in Papua New Guinea-an overview' in D. Hegarty (ed.), Electoral Politics in Papua New Guinea: studies in the 1977 National Elections, University of Papua New Guinea Press, Port Moresby.

Hegarty, D. (ed.), 1983b. Electoral Politics in Papua New Guinea: studies in the 1977 National Elections, University of Papua New Guinea Press, Port Moresby.

Horowitz, D.L., 1985. Ethnic Groups in Conflict, University of California Press, Berkeley. 
Horowitz, D.L., 1991a. A Democratic South Africa? Constitutional Engineering in a Divided Society, University of California Press, Berkeley.

Horowitz, D.L., 1991b. 'Making Moderation Pay: the comparative politics of ethnic conflict management' in J. Montville (ed.), Conflict and Peacemaking in Multiethnic Societies, Lexington Books, New York.

Hughes, C.A., 1990. "The rules of the game' in C. Bean, I. McAllister and J. Warhurst (eds), The Greening of Australian Politics: the 1990 Federal Election, Longman Cheshire, Melbourne.

King, P., (ed), 1989. Pangu Returns to Power: the 1982 elections in Papua New Guinea, Political and Social Change Monograph 9, Department of Political and Social Change, Research School of Pacific Studies, The Australian National University, Canberra.

Lijphart, A., 1991. 'The Alternative Vote: a realistic alternative for South Africa?', Politikon 18(2):91-101.

Oliver, M. (ed.), 1989. Eleksin: the 1987 National Election in Papua New Guinea, University of Papua New Guinea, Port Moresby.

Papadakis, E. and Bean, C., 1995. 'Independents and minor parties: the electoral system', Australian Journal of Political Science (special issue) 30:97-110.

Premdas, R., 1995. Ethnic Conflict and Development: the case of Fiji, Avebury, Aldershot.

Reilly, B., 1996. 'The Effects of the Electoral System in Papua New Guinea' in Saffu, Y. (ed.), The 1992 PNG Election: change and continuity in electoral politics, Department of Political and Social Change, Research School of Pacific and Asian Studies, The Australian National University, Canberra.

Reilly, B., 1997a. 'Preferential voting and political engineering: a comparative study', The Journal of Commonwealth and Comparative Politics 35(1):1-19.

Reilly, B., 1997b. 'The alternative vote and ethnic accommodation: new evidence from Papua New Guinea', Electoral Studies 16(1):1-11.

Reilly, B. and Maley, M., 1996. The Single Transferable Vote and the Alternative Vote Compared, paper presented to conference on 'Elections in Australia, Ireland and Malta under the Single Transferable Vote', organised by the Centre for the Study of Democracy, University of California, Irvine, 14-15 December 1996, unpublished. 
Reynolds, A., 1995. 'Constitutional Engineering in Southern Africa', Journal of Democracy 6(2):86-99.

Saffu, Y., (ed.), 1996. The 1992 PNG Election: change and continuity in electoral politics, Department of Political and Social Change, Research School of Pacific and Asian Studies, The Australian National University, Canberra.

Sartori, G., 1968. 'Political Development and Political Engineering', Public Policy 12:261-98.

Sisk, T., 1996. Power Sharing and International Mediation in Ethnic Conflicts, United States Institute of Peace Press, Washington DC.

Standish, W., 1996. 'Elections in Simbu: towards gunpoint democracy?' in Y. Saffu (ed.), The 1992 PNG Election: change and continuity in electoral politics, Department of Political and Social Change, Research School of Pacific and Asian Studies, Australian National University, Canberra.

Stone, D., (ed.), 1976. Prelude to Self-Government: electoral politics in Papua New Guinea 1972, Research School of Pacific Studies, The Australian National University and University of Papua New Guinea, Canberra and Port Moresby. 